\title{
CONGESTÃO PULMONAR CRÔNICA
}
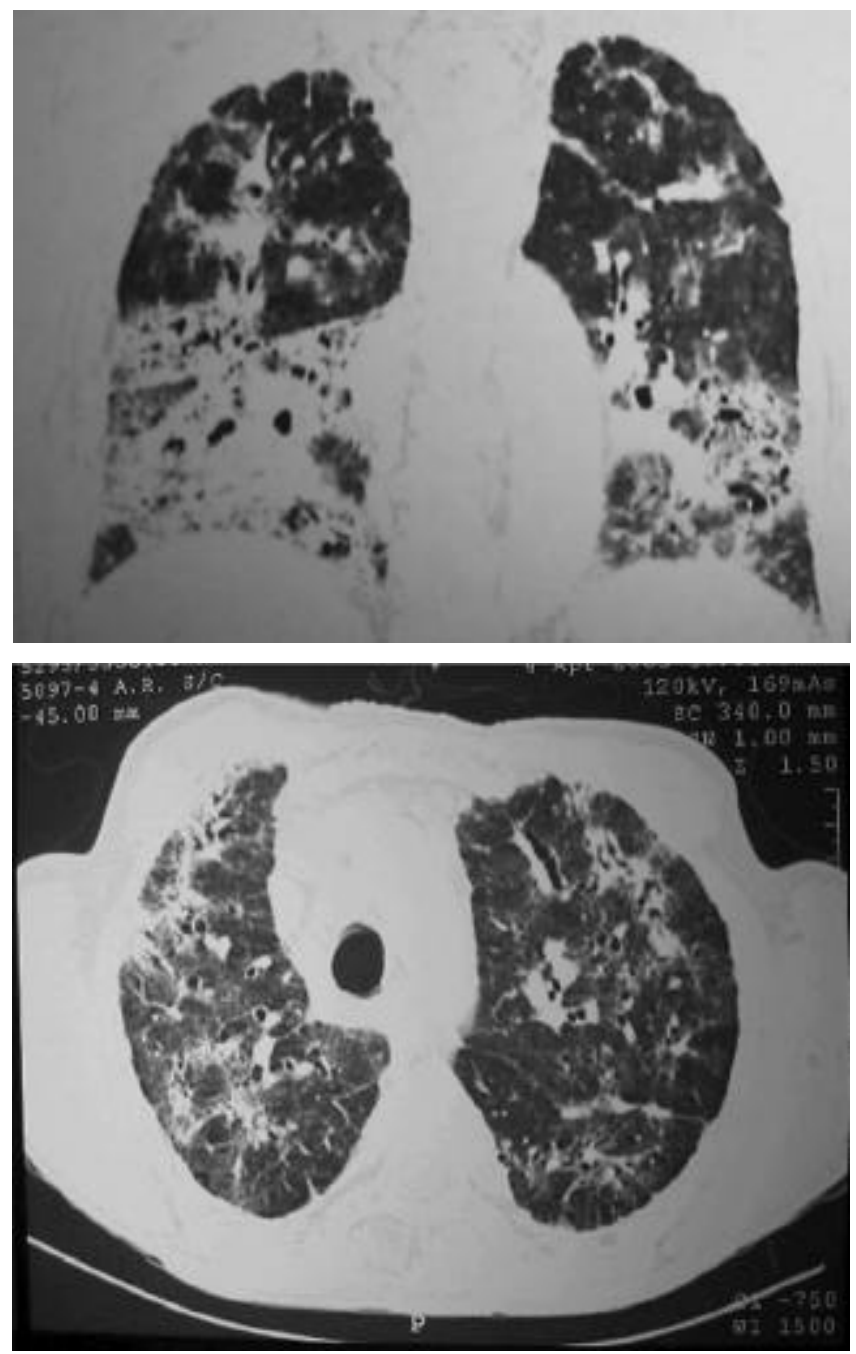

Paciente de 70 anos, sexo masculino, com diagnóstico de valvopatia mitral - estenose mitral grave (área valvar de $0,8 \mathrm{~cm}^{2}$ ) - em acompanhamento ambulatorial há aproximadamente dez anos. Evoluiu nosúltimos meses com piora de classe funcional, apresentando dispnéia e cansaço aos mínimos esforços, atribuído à piora de insuficiência cardíaca congestiva.

A radiografia de tórax mostrou um infiltrado peri-hilar bilateral sugestivo de pneumopatia intersticial, podendo ser de origem pulmonar primária ou de congestão pulmonar crônica passiva. Foram realizados exames complementares para pesquisa de pneumo patia associada por meio de tomografia computado rizada de tórax, lavado broncoalveolar e pesquisa de agentes oportunistas, os quais resultaram negativos.

A intensidade e a magnitude dos achados evidenciados na radio grafia e na tomografia de tórax não representam as imagens habitualmente asso ciadas à congestão pulmonar acentuada de história recente. É possível que, neste caso, a longa evolução da doença secundária à estenose mitral seja responsável pelos achados atípicos.

Pai Ching Yu, lliana Borges, luiz Carlos de A. Filho, Otávio Mangili, 